\title{
Feminine Oppression: A Study of the Conflict in Kashmir
}

\author{
Abdul Basit Naik ${ }^{1}$
}

\section{ABSTRACT}

Kashmir predicament is not merely the problem of men but women are more pretentious as compared to men. The Kashmir crisis started after the British withdrew from the Indian subcontinent in 1947, but real chaos started from 1989 onwards. This paper will analyze the varied atrocities and assorted extent of violence committed against women from 1989 to 2011.

Violence against women (VAW) was not acknowledged as a human rights violation by the domestic and international community for a number of years. It was first addressed at the United Nations Nairobi conference in 1985. Women have been subjugated in Kashmir from last two decades by Security forces. Hundreds of victims were raped, tortured and murdered in reprisal attacks. Violence against women in valley exists in various forms. They are often beaten, mutilated, burned, sexually abused and raped. Such violence is a major obstacle in achieving peace and harmony in the state.

Keywords: Rape, Molestation, Eve Teasing, Killing, Murder, Forces, Militants, Displacement and Oppression

Since 1989, crisis in Kashmir valley has generated political and social turmoil that has eroded the cultural syncretism of Kashmir. It is generally believed that the traditional society of Kashmir about 60 years back was absolutely crime-free. The dominant majority of population had neither witnessed nor heard of any major crimes committed by its members. But, today, the same society stands at its opposite extreme. We all are first-hand witness to the emergence of minor and major crimes, especially violence against women in Kashmiri society. This has happened in a brief period of three to four decades in a particular social context with specific factors contributing to its dynamics and continuity. Broadly speaking, this alarming situation has emerged in the valley in the background of two distinctive processes of militarization and modernization.

The first factor has unleashed a wave of violence against societal groups, classes and communities, especially women. While the misuse/partial-use of gun by Security forces and others led to series of violent acts against women, the state-sponsored gun in the hands of military and para-military forces led to all sorts of excesses against women, including abusing

\footnotetext{
${ }^{1}$ Research scholar, Department of Woman's Education, Maulana Azad National Urdu University, Hyderabad, Telangana State, India.

(c) 2015 I A Naik; licensee IJIP. This is an Open Access Research distributed under the terms of the Creative Commons Attribution License (http://creativecommons.org/licenses/by/2.0), which permits unrestricted use, distribution, and reproduction in any Medium, provided the original work is properly cited.
} 
their chastity. It seems legitimized by draconian laws like Disturbed Areas Act and Armed Forces Special Power Act. It has now been established that violence against Kashmiri women, especially rape, has been used by Security forces as a weapon to impose collective punishment. The second set of factors is directly related to the process of modernization, particularly urbanization, industrialization, cultural-media exposure, migration, secularization, materialistic orientation, value-free environment, moral degradation and so on.

Moreover, the fact stands with strong evidence that molestation and rape against women in Kashmir was started in an organized way by these forces. The rape incidents in Kunan Poshpora, Kupwara, Trehgam and at various other places in the valley are live examples. The gruesome rape and subsequent murder of two women, Assiya and Neelofer, in Shopian represent the climax in this wave of violence against women. Several close relatives were gunned down by the security forces, when they tried to protect the chastity of women in Kashmir.

Lot of empirical research has been carried out on this issue at national as well as at international level. The political stalemate of India and Pakistan has led to the abuse and suffering of women in this particular area. This issue of political stalemate is important because of the grave situation it has put Kashmir in; it remains an integral issue to one of the most important global crises of our times. (ShelaniVanniasinkam, 2010).

In Kashmir Valley and the hill districts girdling it, 1989-90 saw a popular upsurge for selfdetermination which brought women, men and children out on the streets raising the slogans for AZADI. Within the mass popular protest was the undertow of a fledgling armed militancy. The Indian state retaliated with severe repression and military force. In the ensuing armed conflict, an estimated seventy thousand people have been killed; more than two thousand have disappeared or are in illegal detention. There are fifteen thousand widows and thousands of half widows of the disappeared. A generation has grown up which has known nothing other than armed conflict. The social capital of Kashmir has been destroyed as multiple armed agencies are at large with little or no accountability. More than half a million people have been displaced, (Aparna Rao, 2008).

According to Seema Shekhawat (2009), displacement is one of the stark realities of the Kashmir conflict. It remains dwarfed by the attention that the conflict itself has drawn. About ten categories of internally displaced people can be identified. These people have been uprooted either due to the external dimension of the conflict in the form of India-Pakistan hostility, or the internal dimension of the conflict in the form of ongoing violent militancy in Indian state of Jammu and Kashmir. The author focuses on a particular group of displaced people called the Kashmiri Pundits, as their displacement is considered a prominent factor in the rupture of the cohesive fabric of Kashmiri society. In connection with the increased attention of the international community to Women rights in the decades, the international society has become aware of the specific challenges women have to face in times of conflict. A large number of armed groups have been fighting either for independence, integration with Pakistan or simply for 
more autonomy to Jammu and Kashmir since 1989. It is estimated that Forty seven to seventy seven thousand people have fallen victims to the conflict during this time.

A study done by Medecins Sans Frontiers in mid 2005 reveals that Kashmiri women are amongst the worst sufferers of sexual violence in the world. It further mentions that since the beginning of the armed struggle in Kashmir in 1989, sexual violence has been routinely perpetrated on Kashmiri women, with 11.6 percent of respondents saying they were victims of sexual abuse. Interestingly, the figure is much higher than that of Sierra Leone, Sri Lanka and Chechnya. The state home department has no specific data in this regard for the last seventeen years, (Siddiqui, Saeed Ur Rehman.2006).

In Kunan Poshpora, a small village in Kashmir, the soldiers of fourth Rajputana Rifles allegedly raped about 53 women on the unfortunate night of February 23, 1991, during a search operation while men were taken away from their homes and interrogated. The ages of women raped ranged from 13 to 80 years. According to newspaper reports, on June 17,1994, troops of Rashtriya Rifles accompanied by two officers Major Ramesh and Major Rajkumar entered into village Hyhama and allegedly raped and molested seven women. In another incident, troops raped a mentally ill old woman in her house in Barbarshah in Srinagar on January 5, 1991. Medical reports confirmed rape and locals lodged an FIR with the concerned police station, but the police did no investigation. She later died in 1998 while the FIR still awaits action from the state government. In another gruesome incident, an army Major in Badra, Handwara, raped Aisha, a 29-year-old woman and her 10-year-old daughter, Shabnum. These being just a few examples, incidents like these are plenty in Kashmir and ironically pass unheeded. Due to immunity of troops from prosecution and their own court martial proceedings, which are far from being unbiased, they are left free to do. (Siddiqui, Saeed Ur Rehman.2006).

In Kashmir valley before this crisis, women enjoyed greater mobility and visibility than women of other states in the country. (Lawrence, W. 1999). Practices such as rapes, molestation and eve teasing were not very prevalent in the region. This often was cited to portray a picture of equity between men and women in the region and has given rise to the presumption that violence against women is not a major concern in the area. As such the crime level before 1989 was very meager in Kashmir valley.

The crisis situation prevalent in Kashmir valley has intensified the violence against women. Although all the members of communities are affected by the armed atrocities, the impact on women and girls is far greater because of their status in society and their gender. Women in Kashmir valley get directly or indirectly affected by the crisis both by security forces and local inhabitants. Molestation, eve teasing and murder of women is prominent from last two or three decades in Kashmir. 


\section{DEATH}

According to the Kashmiri-Canadian Council, 47,455 Kashmiri’s have died since October 1989. Security forces and other agencies killed hundreds of women suspecting them to be the militant informers or relatives of militants. Several women were first raped and then killed by security forces like on Friday 29 May 2009, Aasiya Jan and her pregnant sister-in-law, Neelofar were raped and then killed.

I visited different affected areas of Kashmir and met various victims, in total hundred respondents were questioned and their responses are as under:

\begin{tabular}{|l|l|l|l|l|l|l|}
\hline $\begin{array}{l}\text { Total } \\
\text { Respondents }\end{array}$ & $\begin{array}{l}\text { Killed by } \\
\text { Rajputana } \\
\text { Rifles }\end{array}$ & $\begin{array}{l}\text { Killed } \\
\text { by BSF }\end{array}$ & $\begin{array}{l}\text { Killed by } \\
\text { CRPF }\end{array}$ & $\begin{array}{l}\text { Killed } \\
\text { by JKP }\end{array}$ & $\begin{array}{l}\text { Killed by } \\
\text { Surrendered } \\
\text { Militants }\end{array}$ & $\begin{array}{l}\text { Killed by } \\
\text { Others }\end{array}$ \\
\hline 100 & 70 & 20 & 05 & 01 & 01 & 03 \\
\hline
\end{tabular}

Result: Out of 100 respondents 96 believe the innocent people of Kashmir are killed by security forces and 3 believe that innocent people are killed by some unidentified persons and 1 believe the surrendered militants are responsible for innocent killings in Kashmir.

\section{RAPE}

Hundreds of women have been raped with impunity and most of them go unreported given the social stigma and fear of retribution by the State. The government has been quick to deny and cover-up most of those cases which do get reported. The reported gang-rape of nine women at Shopian in October 1992 by army unit was dismissed off-handedly after investigation by army and police, the very units charged with the crime, despite solid medical evidence to the contrary; no independent investigation by an impartial agency was carried out (South Asia Human Rights Documentation Centre 2005). The reported mass rape of over forty women in Konan Poshpurain February 1991 was also handled in a similar evasive manner; the complaint was not investigated in a timely manner by an impartial agency and the medical evidence was dismissed without good cause and Amnesty's request for medical records were ignored; the women still remain unmarried or have been deserted by their husbands and one of the victims who was nine months pregnant during the incident delivered a baby with a fractured left arm in 1991; the then Governor Girish Saxena who denied the incident admitted to mass rapes in the past by the Indian forces however. Rapes continue to be reported, an example being the April $17^{\text {th }}$ gang-rape of a 17-year old girl in Pahalgamand May 2009 rape and murder of two young women by Indian armed forces in Shopian village.

Rape by Indian security forces most often happen during crackdowns, cordon-and-search operations, during which men are held for identification in parks or school yards while security 
forces search their homes. Besides rape, women have been used as human shields too. Besides the impact of armed violence on women and that of the ambiguous transformations, which occurred, a lot of women seemed to be joining the armed insurgent movement.

Sample: 100 respondents from different affected areas were questioned

\begin{tabular}{|l|l|l|l|}
\hline Culprits & Molestation & Rapes & Eve Teasing \\
\hline Rajputana Rifles & 38 & 66 & 22 \\
\hline BSF & 22 & 15 & 18 \\
\hline CRPF & 14 & 07 & 24 \\
\hline JKP & 20 & 02 & 28 \\
\hline Surrendered Militants & 06 & 04 & 08 \\
\hline Others & 00 & 06 & 00 \\
\hline
\end{tabular}

Result: out of 100 respondents 94 believe that women molestation in Kashmir is done by security forces, 90 believes women are raped by security forces and 92 believe eve teasing is done by security forces.

\section{CONCLUSION}

It is clear from the above statistical data that more than $90 \%$ of Kashmiri Oppressed people particularly women believe that security forces are responsible for their plight. It could be said that uncertainty in Kashmir is a political issue which not only brings turmoil in the lives of the local people of the valley but also impacts the international relations. The army and paramilitary forces violate human rights in Kashmir valley and mostly affect the women in the region. The members of government agencies commit all types of violence against women in Kashmir valley. Besides, local people also, due to frustration and under other pressures, cause physical and psychological violence to women in the family.

The government of India should encourage swift investigation of rapes by security forces and paramilitary forces in Kashmir. Security personnel, including police, army and paramilitary, responsible for rape should be prosecuted in civilian courts. Only with such trials and appropriate punishments, will these forces receive the clear, unequivocal message that, rape is condoned by their superiors. Those found guilty of rape should be punished regardless of rank. The punishments should not be less than what is specified under civilian law. The results of these investigations and the punishments should be made public as a means of giving the people of Kashmir a reason to believe in the government's commitment to justice and the rule of law. Medical workers who have examined and treated rape victims should be protected from abuse. Medical facilities, including private licensed physicians, should be encouraged to give testimony and introduce physical evidence in court with regard to rape and other forms of sexual and physical abuse. (PARVAIZ) 


\section{REFERENCES}

Amnesty International.(1993)."India: New Allegations of Rape by Army Personnel in Jammu and Kashmir " Al Index: ASA 20/02/93, January 1993.

Asia watch and physicans and Human Rights. (1993). The Human Rights crisis in Kashmir: A Pattern of Impunity,New York,Asia. pp.98-107.

Chinkin, C. (1994). Rape and Sexual Abuse of Women in International Law. European Journal of International Law.

Kaul, A. (2008). Kashmiri women see a window of opportunity. kashmir : OneWorld.net.http://southasia.oneworld.net/news/kashmiri-women-see-a-window-ofopportunity\#.VdlVGPmqqko. Amnesty International, Torture and Deaths in Custody in Jammu and Kashmir, 1995.

Lamb, A. (1991). Kashmir: A Disputed Legacy, 1846-1990. Oxford Books; ISBN-10: 0907129064.

M. L.Koul, Kashmir, Past and Present, unravelling the mystique, SehyogPrakashan, New Delhi, 1994, P.148.

Parvaiz, A. (2008). INDIA: Kashmiri Women Repose Faith in Electoral Politics. SRINAGAR: Inter Press Services .http://www.ipsnews.net/2008/12/india-kashmiri-women-reposefaith-in-electoral-politics/

\section{Webs}

http://articles.timesofindia.indiatimes.com/2011-1012/india/30270597_1_interlocutors-radhakumar-dileep-padgoankar http://indiatoday.intoday.in/story/interlocutors-want-militants-in-jammu-and-kashmirfreed/1/148717.html accessed on 15 feb 2012 http://www.enotes.com/topic/Indo-Pakistani_War_of_1965, accessed on 15 feb 2012 